\title{
KOMITMEN KARYAWAN PADA PERENCANAAN PRODUKSI DALAM RANGKA EFEKTIFITAS PELAKSANAAN PENGELOLAAN LIMBAH STUDI KASUS DEPARTEMEN POLIMER INDUSTRI TEKSTIL PT TIFICO
}

\author{
Betsy Sihombing1) \& Sortawati Siregar ${ }^{2)}$ \\ 1)\&2) Program Studi Manajemen Lingkungan \\ Program Pascasarjana Universitas Negeri Jakarta
}

\begin{abstract}
Have been done research about commitment of employees in production planning for the effectiveness of waste management implementation at the Department of Polymer PT. TIFICO. This research was conducted at the Factory of PT. TIFICO Tangerang in 2010. Hope this research can be useful to encourage increased employee commitment in production planning to improve the effectiveness of waste management Titan slurry (TiO2), which pertained hazardous materials and toxic waste (B3). This study is descriptive research, and the data in this study are represented in the frequency distribution table and histogram of the commitment of employees in production planning for the effectiveness of waste management implementation. Based on this research, the effectiveness of waste management implementation can be done by the Department of Polymer PT. TIFICO with the approach of the commitment of employees at production planning in the process of polymerization. With a sense take the part of the stimulation of the employee's commitment to creating a new innovation in the production process.So also with the determine the working methods of production planning in the polymerization process can reduce the amount of waste Titan of the process.
\end{abstract}

Key words: Management, Waste

\section{PENDAHULUAN}

Konsep pengelolaan limbah saat ini telah bergeser dari pengolahan limbah (waste treatment) kearah pencegahan timbulan limbah (waste prevention) dan pemanfaatan limbah menjadi produk (waste to product). Pada kenyataannya pengolahan limbah memerlukan biaya investasi dan operasi yang tinggi sehingga mengurangi keuntungan perusahaan. Dengan biaya yang tinggi tersebut seringkali banyak perusahaan yang tidak melakukan pengelolaan limbah dan membuang langsung ke lingkungan. Disamping itu pengolahan limbah juga seringkali tidak memecahkan masalah lingkungan, karena pada beberapa proses pengolahan hanya memindahkan pencemar dari suatu media ke media lain.
Pada mulanya pengelolaan limbah lebih ditekankan pada pengolahan limbah. Namun pada dekade akhirakhir ini, berbagai negara terutama negara maju lebih menekankan kepada usaha preventif, yaitu menekan jumlah limbah yang dihasilkan oleh proses produksi. Dalam pelaksanaan pengelolaan limbah, upaya pertama yang harus dilaksanakan sebelum melakukan pengolahan limbah adalah upaya preventif, yaitu pengurangan volume atau jumlah limbah, yang lebih dikenal dengan minimisasi limbah.[Sudrajat, 1998] Untuk mencapai upaya minimalisasi limbah tersebut maka perlu dilakukan perencanaan produksi. Perencanaan produksi disini diperlukan agar implementasi pelaksanaan produksi dapat terlaksana sesuai dengan tujuan dan 
sasaran yang telah ditentukan. Dalam perencanaan produksi perlu pendekatan langkah-langkah sebagai berikut: a) memutuskan tujuan-tujuan perencanaan, yaitu meningkatkan efisiensi, efektifitas, kapasitas atau semangat kerja karyawan, b) memilih proses atau sistem produktif yang relevan yaitu operasi keseluruhan atau beberapa bagian operasi, c) Menggambarkan proses transformasi yang ada sekarang dengan bantuan bagan-bagan proses dan pengukuran efisiensi, d) Mengembangkan disain proses yang diperbaiki melalui aliran-aliran proses dan/atau masukan-masukan yang digunakan. Dalam penyusunan perencanaan produksi maka perlu disusun baganbagan proses yang digunakan untuk menggambarkan dan memperbaiki proses transformasi dalam sistemsistem produktif. Dalam peningkatan efektifitas atau efisiensi proses-proses produksi, beberapa atau seluruh elemen proses berikut mungkin perlu diubah seperti bahan mentah, disain produk, disain pekerjaan, tahap-tahap pemrosesan yang digunakan, sistem pengawasan manajemen dan peralatan. [Handoko,1987]

Dengan adanya bagan proses yang disusun sebagai perencanaan produksi, maka dapat diketahui tahapan-tahapan proses yang perlu dievaluasi dan diperbaiki. Perencanaan dapat juga disebut merupakan fungsi memilih sasaran perusahaan secara kebijaksanaan, program dan pemilihan langkah-langkah apa yang harus dilakukan, siapa yang melakukan dan kapan aktivitasnya dilaksanakan. Pada umumnya dalam perencanaan produksi target yang diinginkan adalah perencanaan produksi yang baik, namun merencanakan proses produksi bukanlah hal yang mudah karena banyak faktor yang mempengaruhi.
Salah satu faktor yang mempengaruhi adalah adanya komitmen karyawan yang merupakan faktor input dalam proses produksi. Yang dimaksud dengan input adalah semua sumber (resources) yaitu sarana dan prasarana yang digunakan dalam proses produksi barang maupun jasa, seperti tenaga kerja (man), biaya (money), bahanbahan pokok (materials), peralatan atau mesin (machine) cara kerja (method), pemasaran dan pelayanan (market atau service), termasuk juga waktu (time). Perencanaan produksi pada Departemen Polimer PT Tifico dapat dilihat pada proses produksi Continous Process dan Bath Process untuk menghasilkan Polyethylene Terepthalate (PET).

Saat ini pengelolaan limbah industri dapat dilakukan dengan berbagai pendekatan yang bertujuan untuk penghematan biaya sehingga keuntungan yang diperoleh akan semakin besar. Adapun beberapa upaya pengelolaan limbah industri adalah minimisasi limbah, pencegahan pencemaran, produksi bersih (strategi pengelolaan lingkungan yang bersifat preventif, terpadu dan diterapkan secara kontinu pada proses produksi, produk dan jasa untuk meningkatkan eko-efisiensi sehingga mengurangi risiko terhadap kesehatan, manusia dan lingkungan), eco-efficiency (strategi yang menggabungkan konsep efisiensi ekonomi berdasarkan prinsip efisiensi penggunaan sumber daya alam, pembatasan pemakaian bahanbahan berbahaya, desain berwawasan lingkungan, produktivitas ramah lingkungan, produk ramah lingkungan, mengubah limbah menjadi produk, dan pertukaran limbah.

Bagi industri yang menghasilkan limbah B3 wajib melakukan pengelo- 
laan terhadap limbah B3 tersebut. Dalam pengelolaan limbah B3 tersebut dapat dilakukan dengan cara mereduksi limbah B3, mengolah limbah B3 dan/atau menimbun limbah B3. Pengolahan limbah B3 oleh industri dapat dilakukan sendiri oleh penghasil limbah B3 atau penghasil limbah B3 dapat menyerahkan pengolahan dan/atau penimbunan limbah B3 yang dihasilkannya itu kepada pengolah dan/atau penimbun limbah B3. Saat ini di Indonesia banyak perusahaan jasa pengolah dan/atau penimbun limbah B3. Dalam pelaksanaannya, pengelolaan limbah dapat dilakukan dengan cara mereduksi limbah B3. Hal tersebut sesuai dengan yang ditetapkan oleh Menteri Negara Lingkungan Hidup: Reduksi limbah B3 dapat dilakukan melalui upaya menyempurnakan penyimpanan bahan baku dalam kegiatan proses (house keeping), substitusi bahan, modifikasi proses, serta upaya reduksi limbah B3 lainnya. Dalam melakukan upaya-upaya tersebut dibutuhkan adanya komitmen karyawan pada perencanaan produksi yang tertuang dalam manajemen pengelolaan limbah. Dengan adanya komitmen karyawan pada perencanaan produksi diharapkan adanya efektifitas pelaksanaan pengelolaan limbah sehingga limbah yang dihasilkan dapat di minimalisasi.

Komitmen karyawan mengandung makna sebagai bentuk keterikatan karyawan terhadap perusahaan, hal tersebut dapat ditunjukkan dalam kesediaan karyawan untuk melakukan yang terbaik bagi perusahaan melalui perencanaan produksi yang jelas dan melibatkan hubungan secara aktif dalam perusahaan. Dengan demikian lebih memungkinkan individu tersebut memberikan segala sesuatu yang dimiliki pada dirinya untuk menunjang terealisasinya tujuan maupun kelangsungan hidup perusahaan. Permasalahan pengelolaan limbah dapat diselesaikan jika ada komitmen yang berasal dari diri karyawan untuk menyelesaikan pekerjaan sesuai dengan yang telah direncanakan. Pelaksanaan pekerjaan tersebut merupakan tanggung jawab yang dilaksanakan dengan adanya motivasi yang dimiliki. Salah satu tantangan yang dihahadapi oleh perusahaan adalah menciptakan hasil produksi dengan jumlah limbah yang lebih kecil.

Dalam pelaksanaan pekerjaannya sehari-hari, perlu adanya kejelasan dan fungsi dari masing-masing karyawan, sehingga timbul komitmen untuk bertanggung jawab melaksanakan tugas yang dibebankan kepadanya sesuai dengan rencana produksi. Seseorang hanya mungkin dapat melaksanakan pekerjaannya secara efektif, jika mereka telah mengetahui secara pasti tentang perannya didalam sebuah organisasi tempat kerjanya. Dengan mengetahui perannya dalam organisasi maka seseorang akan menyusun perencanaan dalam pekerjaannya, termasuk dalam hal ini perencanaan produksi. Seseorang yang dapat memahami perannya dan menerima perannya, tentu akan secara konsekuen melaksanakan semua tugas yang melekat pada perannya itu dengan sebaik-baiknya. Tugas atau tanggung jawab yang diberikan kepada karyawan bukan dipandang sebagai beban yang memberatkan atau menjemukan, melainkan merupakan suatu tantangan yang menarik untuk diselesaikan dan mungkin akan menimbulkan suatu kepuasan kerja bagi dirinya apabila dapat menyelesaikannya. 
PT. TIFICO yang berdiri pada tanggal 25 Oktober 1973 adalah Perusahaan Penanaman Modal Asing (PMA) di Indonesia dari Jepang, yaitu Teijin Limited. Perusahaan tersebut merupakan salah satu industri yang memasok bahan baku bagi industri-industri dalam negeri yang menggunakan polyester sebagai bahan bakunya. Pabrik ini menggunakan bahan utama berupa Mono Ethylene Glycol (MEG), dan Purified Therepthalic Acid (PTA), dan menggunakan Antimon Trioxide $\left(\mathrm{Sb}_{2} \mathrm{O}_{3}\right)$ dan Natrium Asetat ( $\left.\mathrm{CH}_{3} \mathrm{COONa}\right)$ sebagai katalis. Juga digunakan Dihydroxy Ethoxy 5 Sulfo Sodium Therephtalic Acid dan Titan Dioxide $\left(\mathrm{TiO}_{2}\right)$ sebagai bahan aditif. Divisi Produksi dan Teknologi PT. TIFICO Tbk dibagi 6 (enam), yaitu Departemen Polimer, Departemen Staple Fiber Manufcaturing dan Departemen Filamen Yarn Manufacturing, Departemen Maintenance, Departemen Electric dan Instrumen, dan Departemen Utility. Proses produksi khususnya yang dilakukan di Departemen Polimerisasi PT.TIFICO Tbk terbagi atas 5 (lima) proses utama, yaitu : proses pembuatan PTA (Pure Terepthalate Acid) Slurry, Proses Direct Esterification, Proses Polycondensation Autoclave, Proses Chip Cutting, dan Proses Pembuatan Catalyst dan Additive sebagai pendukung dalam stabilisasi kualitas produk. Pada penelitian ini akan membahas limbah Titan yang dihasilkan pada Continous Process (CP) dan Batch Process (BX) untuk menghasilkan Polyethylene Terepthalate (PET). PET yang dihasilkan digunakan untuk bahan baku dalam produksi pembuatan benang textile (Yarn), kapas sintetis (Staple Fiber), lapisan film kemasan makanan dan produk lainnya, benang pengisi ban (Tired Cord). Continous Process (CP) adalah proses produksi yang berlangsung secara berkelanjutan (continuous). Batch Process (BX) adalah proses produksi yang berlangsung secara bertahap dan mempunyai jeda waktu dalam reaktor untuk setiap siklus proses 3 (tiga) jam. Dari Continous Process (CP) dan Batch Process (BX) limbah yang dihasilkan adalah TiO2 Slurry (larutan TiO2 yang memiliki kekentalan agak tinggi, Spesific Gravity > 1.0). Limbah TiO2 tersebut dihasilkan pada persiapan TiO2 dan proses TCD.

Permasalahan yang muncul pada Departemen Polimer adalah dilihat dari komposisi staf yang ada saat ini adalah hanya memiliki jumlah karyawan 77 orang. Sebelumnya, pada tahun 2002 departemen Polimer memiliki karyawan sebanyak 166 orang. Pada Tahun 2003, PT. Tifico mengeluarkan kebijakan Program Pensiun Dini (PPD). Dengan adanya program PPD tersebut maka terjadi penurunan jumlah karyawan pada departemen Polimer menjadi 146 orang. Pada tahun 2004 dengan adanya PPD jumlah karyawan menjadi 117 orang. Sedangkan pada PPD 2005 terjadi pengurangan jumlah karyawan menjadi 92 orang. Hingga saat ini dengan jumlah karyawan hanya 77 orang dan dengan latar belakang pendidikan yang bervariasi (minimnya jumlah karyawan dengan latarbelakang ilmu kimia). Sumberdaya manusia yang berkualitas, erat kaitannya dengan mutu tenaga kerja. Mutu tenaga kerja dapat diukur antara lain dengan indikator dimensi pendidikannya, kondisi fisik dan etos kerjanya.

Dengan demikian maka perlu adanya komitmen karyawan yang tertuang dalam etos kerjanya dalam menyusun perencanaan produksi sebagai upaya meningkatkan efektifitas pelaksanaan 
pengelolaan limbah. Efektifitas pengelolaan limbah yang dilakukan merupakan sebagai salah satu upaya untuk meminimalisasi jumlah limbah TiO2 tergolong limbah bahan berbahaya dan beracun (B3) pada industri tekstil tersebut. Komitmen karyawan tersebut tertuang dalam manajemen pengelolaan limbah yang akan dilakukan yang dalam hal ini minimisasi jumlah limbah dengan pendekatan pada perencanaan produksi. Upaya meminimalisasi jumlah limbah polimerisasi ini merupakan langkah untuk mengurangi biaya pengolahan limbah B3 yang dilakukan. Mengingat keterbatasan jumlah karyawan dan latarbelakang pendidikan yang bervariasi pada Departemen Polimer PT. TIFICO maka perlu adanya komitmen karyawan dalam perencanaan produksi sebagai upaya efektifitas pengelolaan limbah. Komitmen karyawan tersebut tertuang pada perencanaan produksi yang dalam hal ini adalah persiapan dan proses TCD, sebagai sumber timbulnya limbah Titan atau TiO2. Sehubungan dengan hal tersebut di atas, perlu dilakukan kajian apakah dengan adanya komitmen karyawan yang tertuang pada perencanaan produksi dapat menyebabkan efektifitas pengelolaan limbah.

\section{ACUAN TEORITIK}

Untuk mengetahui kemampuan orang dalam melaksanakan tugas maupun banyaknya motivasi untuk bekerja secara efektif maka perlu adanya interaksi atau pengaruh timbal-balik antara pimpinan dan bawahan. Dalam pendayagunaan faktor-faktor produksi dan teknologi di dalam suatu organisasi yang baik, faktor-faktor yang perlu diperhatikan adalah faktor efisiensi, efektifitas dan produktivitas. Menurut Jusuf Suit dan Almasdi, efektifitas adalah ketepatan suatu tindakan atau kesempurnaan (jaminan) hasil suatu pekerjaan.[Jusuf Suit, 1996, h.66]

Dalam pelaksanaan tugas untuk mencapai efektifitas, perlu adanya keterbukaan pemimpin dan keberanian untuk mendiskusikan hal-hal yang menjadi sumber-sumber ketidaksesuaian harapan, yang pada umumnya disebabkan oleh perbedaan persepsi, mungkin akan dapat membantu meningkatkan kesadaran diri dari pemegang peran, serta meningkatkan kepercayaan diri dari anggota-anggota, karena mereka diperhatikan oleh atasan. Hal tersebut akan berpengaruh pada terhadap kepuasan kerja atau semangat kerja, sehingga akan meningkatkan efektifitas pelaksanaan tugas. [T. Hani H, h.179]

Berdasarkan pengertian di atas dapat dikatakan bahwa apabila sasaran atau tujuan telah tercapai sesuai dengan yang direncanakan sebelumnya, maka dapat dikatakan telah terdapat unsur efektifitas. Efektifitas juga dapat dikatakan sebagai kemampuan untuk melakukan hal yang tepat atau untuk menyelesaikan dengan baik. Menurut pendapat Stoner, Freeman dan Gilbert, efektifitas hakikatnya adalah melakukan sesuatu yang tepat. Pernyataan ini menunjukkan bahwa perkerjaan harus mempunyai tujuan yang jelas agar dapat dikerjakan secara tepat dan berhasil mencapai sasarannya. Oleh karena itu untuk mendapatkan suatu pekerjaan yang akan dilaksanakan, perlu usaha memahami secara baik kemudian ditindaklanjuti dengan melakukan secara tepat terarah pada tujuan yang telah ditetapkan. Disamping itu perlu adanya upaya yang harus dilakukan untuk menciptakan kondisi yang menjadikan seorang pekerja efektif dalam pekerjaannya. 
Lebih lanjut Mardiasmo (2002) menjelaskan efektifitas adalah menggambarkan tingkat pencapaian hasil program dengan target yang ditetapkan atau merupakan perbandingan out come dengan out put.[Mardiasmo, 2002] Menurut Gibson 1995; efektifitas dalam konteks perilaku organisasi merupakan hubungan optimal antara produksi, kualitas, efisiensi, fleksibilitas, kepuasan, sifat keunggulan dan pengembangan. Perspektif efektifitas yang menekankan peran sentral dari pencapaian tujuan sebagai kriteria untuk menilai efektifitas. Lebih lanjut disebutkan yang dimaksud dengan efektifitas adalah pencapaian sasaran dari upaya bersama. Derajat pencapaian menunjukkan derajat efektifitas. [Gibson, 1995]

Menurut Terry, pelaksanaan adalah mencakup kegiatan yang dilakukan seorang manajer untuk mengawali dan melanjutkan kegiatan yang ditetapkan oleh unsur perencanaan dan pengorganisasian agar tujuan-tujuan organisasi dapat tercapai.[Terry, h. 9] Pelaksanaan menurut Hamzar, adalah kegiatan yang bersifak fisik sesuai dengan program dan rencana kegiatan yang telah ditetapkan sebelumnya.[Rafinus, 2003, h.5] Pendapat Mufham mengatakan bahwa pelaksanaan adalah tindakan atau aktivitas seluruh komponen manajemen.[Amin, 2006, h.44]

\section{Komitmen Karyawan}

Arti komitmen menurut Longman Dictionary of Contemporary English adalah suatu janji untuk melakukan sesuatu dan suatu kerja keras atau loyalitas dari seseorang. Dengan demikian dapat dikatakan bahwa komitmen adalah suatu janji, kerja keras dan loyalitas seseorang yang diberikan pada organisasi atau perusahaan. Komitmen suatu perusa- haan dapat dilihat dari beragam perspektif. Dari sisi karyawan perusahaan, komitmen dicirikan oleh produktivitas dan penghargaan terhadap karyawan. Dalam kenyataannya komitmen antar karyawan bisa beragam. Mulai dari yang sangat kurang sampai ke yang sangat komitmen. Dalam prakteknya tidaklah cukup hanya menganalisis dari dimensi mana kita melihat komitmen karyawan, tetapi bagaimana pemimpin perusahaan membuat suatu kerangka pendekatan bagaimana meningkatkan komitmen karyawan. Komitmen berarti memberikan pelatihan, alat-alat, sumber daya, kekuasaan, tanggung jawab, kebebasan dan dorongan.[Triguno, h. 59] Bagi seorang pemimpin yang mempunyai visi kuat berarti pemimpin tersebut mendorong karyawan untuk menerima misi organisasi sebagai milik pribadi. Hal tersebut akan dicapai dengan mengembangkan nilai-nilai budaya dan lingkungan partisipatif dalam organisasi yang tetap kondusif untuk menjamin karyawan terus tertantang dan termotivasi.

Komitmen pada organisasi merupakan tingkat sampai dimana seorang karyawan memihak pada suatu organisasi tertentu dan tujuannya, dan berniat memelihara keanggotaan dalam organisasi tersebut.[Robbins, 2003, h.92] Dapat dikatakan komitmen merupakan sebuah ketetapan karyawan dengan menyetujui untuk terus menjalankan misi perusahaan atau misi dari unit-unit perusahaan.[Dessler, 2003, h.17] Dalam hal komitmen, kinerja karyawan perlu juga diperhatikan bahwa karyawan akan bekerja keras apabila merasa bahwa mereka "diperlukan" didalam organisasi.[Rao,1986, h.8] Kinerja karyawan adalah tingkat dimana karyawan mencapai persyaratan-persyaratan pekerjaan, sedangkan 
penilaian kinerja adalah proses yang mengukur kinerja karyawan tersebut.[Simamora, 1995]

Komitmen adalah kapasitas total untuk bekerja dalam menyelesaikan tujuan organisasi dan juga dapat diartikan sebagai keterlibatan pekerja dalam organisasi. Komitmen dapat diartikan sebagai keterikatan. Seseorang yang mempunyai komitmen apabila ia selalu yakin dan terdorong minatnya untuk melakukan tugas dengan baik tanpa perlu diawasi.[Atmosoeprapto, 2002, h.64] Argyris membagi komitmen menjadi dua bagian besar yaitu komitmen eksternal dan komitmen internal. Komitmen eksternal dibentuk oleh lingkungan kerja, komitmen ini muncul karena adanya tuntutan terhadap penyelesaian tugas dan tanggungjawab yang harus diselesaikan, dan manajer serta supervisor sangat berperan dalam menentukan timbulnya komitmen ini. Sedangkan komitmen internal merupakan komitmen yang berasal dari diri seseorang untuk menyelesaikan berbagai tugas, tanggungjawab dan wewenang berdasarkan pada alasan dan motivasi yang dimiliki.[Usmara, 2002] Motivasi adalah proses kesediaan melakukan usaha tingkat tinggi untuk mencapai sasaran organisasi, yang dikondisikan oleh kemampuan usaha tersebut memuaskan kebutuhan sejumlah individu. Motivasi tingkat kinerja karyawan supaya tinggi merupakan masalah organisasi yang penting dan manajer harus mencari solusinya.[Robbins/Coulter, h.129]

Komitmen karyawan terkait juga dengan budaya kerja. Budaya kerja dalam organisasi seperti di perusahaan diaktualisasikan sangat beragam. Bisa dalam bentuk dedikasi atau loyalitas, tanggung jawab, kerjasama, kedisip- linan, kejujuran, ketekunan, semangat, mutu kerja, keadilan, dan integritas kepribadian. Semua bentuk aktualisasi budaya kerja itu sebenarnya bermakna komitmen. Lebih lanjut disebutkan bentuk komitmen karyawan dapat diujudkan antara lain dalam beberapa hal sebagai berikut: a) komitmen dalam mencapai visi, misi dan tujuan organisasi, b) komitmen dalam melaksanakan pekerjaan sesuai dengan prosedur kerja standar organisasi c) komitmen dalam mengembangkan mutu sumberdaya manusia bersangkutan dan mutu produk, d) komitmen dalam mengembangkan kebersamaan tim kerja secara efektif dan efisien dan e) komitmen untuk berdedikasi pada organisasi secara kritis dan rasional. Kegagalan program budaya kerja sebagian besar disebabkan oleh kurangnya komitmen dari puncak pimpinan, dan juga pada diri seseorang. Budaya kerja merupakan suatu organisasi komitmen yang luas dalam upaya untuk membangun SDM, proses kerja, dan hasil kerja yang lebih baik. Budaya kerja akan mampu muncul dalam kinerja seseorang atau sekelompok orang bilamana mereka mempunyai dasar nilai-nilai yang baik atau luhur.[Triguno, 1996, h.59]

Komitmen karyawan terkait juga dengan sistem manajemen. Di Jepang, salah satu ciri terpenting manajemen adalah sistem memperkerjakan karyawan selama seumur hidup. Hal tersebut mencerminkan adanya komitmen yang besar dari perusahaan untuk mempertahankan karyawan, maupun komitmen karyawan dengan perusahaan.[Handoko,1987, h. 217] Dengan demikian kualitas manajemen suatu organisasi yang sudah berada pada kondisi yang baik akan berdampak positif bagi perusahaan dalam mengha- 
dapi persaingan karena produktivitas sumber daya manusianya sudah tinggi.

Dari deskripsi tersebut diatas dapat disintesiskan bahwa yang dimaksud dengan komitmen karyawan adalah dimana seseorang merasa diperlukan oleh perusahaan, sehingga terdorong keinginan untuk melakukan tugas dengan baik untuk mencapai tujuan dan sasaran yang meliputi keberpihakan, tanggung jawab dan motivasi.

\section{Perencanaan Produksi}

Perencanaan adalah menetapkan pekerjaan yang harus dilaksanakan oleh kelompok untuk mencapai tujuan yang digariskan yang mencakup kegiatan pengambilan keputusan, termasuk pemilihan alternatif-alternatif keputusan.[Terry, 2003, h. 17] Dalam pelaksanaan perencanaan diperlukan kemampuan untuk mengadakan visualisasi dan melihat kedepan guna merumuskan suatu pola dari himpunan tindakan untuk masa mendatang. Lebih lanjut Terry mendefinisikan perencanaan merupakan pemilihan dan menghubungkan fakta, menggunakan asumsiasumsi tentang masa depan dalam membuat visualisasi dan perumusan kegiatan yang diusulkan dan memang diperlukan untuk mencapai hasil yang diinginkan. Perencanaan yang efektif harus berdasarkan pada fakta dan informasi, bukan atas dasar emosi atau keinginan. Fakta-fakta yang relevan dengan situasi yang sedang dihadapi berhubungan erat dengan pengalaman dan pengetahuan seorang manajer. Oleh karena itu dibutuhkan cara berfikir yang berefleksi dan juga dapat dibantu oleh imajinasi dan forecast.

Seorang perencana harus mampu menggambarkan pola kegiatan yang diusulkan secara jelas. Jadi sebelum melakukan kegiatan, sebaiknya harus disiapkan terlebih dahulu perencanaannya. Perusahaan perlu melakukan perencanaan sebelum melakukan kegiatan atau produksi. Perencanaan merupakan proses awal yang digunakan untuk memilih tujuan dan bentuk tindakan yang akan dilakukan. Suatu perencanaan adalah suatu aktivitas integratif yang berusaha untuk memaksimumkan efektifitas seluruhnya sebagai suatu sistem.

Menurut Louis A. Allen dalam Dasardasar manajemen M. Manullang disebutkan Planning is the determination of a course of action to achieve a desired result. Jadi perencanaan adalah penentuan serangkaian tindakan untuk mencapai sesuatu hasil yang diinginkan. Lebih lanjut menurut M. Manullang, disebutkan bahwa pada umumnya sesuatu rencana yang baik harus berisikan 6 (enam) unsur yang dapat menjawab pertanyaan sebagai berikut: a) Tindakan apa yang harus dikerjakan? b) Apakah sebabnya tindakan itu harus dikerjakan? c) Dimanakah tindakan itu harus dilaksanakan? d) Kapankah tindakan itu dilaksanakan? e) Siapakah yang akan mengerjakan tindakan itu? f) Bagaimanakah caranya melaksanakan tindakan itu?. Lebih lanjut disebutkan bahwa perencanaan adalah a) pemilihan atau penetapan tujuantujuan organisasi dan b) penentuan strategi, kebijaksanaan, proyek, program, prosedur, metode, sistem anggaran dan standar yang dibutuhkan untuk mencapai tujuan.

Dari deskripsi tersebut di atas dapat disintesiskan bahwa yang dimaksud dengan perencanaan produksi adalah proses awal yang dilakukan dalam penetapan pekerjaan untuk mencapai tujuan dengan hasil yang diinginkan dengan pendekatan menentukan 
metode kerja, perumusan kegiatan dan pengambilan keputusan.

\section{METODOLOGI PENELITIAN}

Penelitian dilaksanakan di Industri Tekstil PT. TIFICO, Departemen Polimer dengan subjek penelitian yaitu karyawan Departemen Polimer PT. Teijin Indonesia Fiber Corporation (TIFICO). Penelitian ini akan mendeskripsikan fakta-fakta dan gambaran secara umum mengenai komitmen karyawan pada perencanaan produksi di Departemen Polimer PT. TIFICO dalam rangka efektifitas pelaksanaan pengelolaan limbah. Unit analisis pada penelitian ini adalah karyawan Departemen Polimer PT. Teijin Indonesia Fiber Corporation (TIFICO) sebagai unit pelaksana yang melakukan efektifitas pelaksanaan pengelolaan limbah dari proses polimerisasi untuk menghasilkan Polyethylene Terepthalate (PET).

Teknik pengumpulan data pada penelitian ini adalah dengan menggunakan angket, yaitu berupa daftar pertanyaan yang harus diisi oleh responden. Angket akan diberikan kepada karyawan Departemen Polimer PT. TIFICO. Pengambilan sampel pada penelitian ini akan dilakukan kepada karyawan Departemen Polimer PT. TIFICO yang latar belakang pendidikannya berbeda-beda.

Teknik analisa yang digunakan pada penelitian ini yaitu dengan analisis deskriptif yang menjelaskan data-data yang diperoleh dari hasil penelitian dengan menggunakan statistik deskriptif kemudian disajikan dengan distribusi frekuensi dan histogram. Penelitian deskriftif yang biasanya disebut juga penelitian taksonomik (taxonomic research) merupakan penelitian yang dimaksudkan untuk eksplorasi dan klarifikasi mengenai sesuatu fenomena atau kenyataan sosial, dengan jalan mendeskripsikan sejumlah variabel yang berkenaan dengan masalah dan unit yang diteliti tanpa mempersoalkan hubungan antar variabel.[Sanafiah,2007,h.20] Dengan demikian penelitian deskriptif tidak menggunakan dan tidak melakukan pengujian hipotesis yang berarti tidak membangun dan mengembangkan perbendaharaan teori. Deskripsi data penelitian dilakukan terhadap tiga variabel yang diukur dalam penelitian ini, yakni variabel komitmen karyawan sebagai variabel pertama, variabel perencanaan produksi sebagai variabel kedua dan variabel efektifitas pengelolaan limbah sebagai variable ketiga.

Efektifitas setiap organisasi sangat dipengaruhi oleh perilaku manusia. Manusia merupakan sumber daya yang umum bagi semua organisasi.[Gibson, h.8] Untuk mencapai tujuan suatu organisasi dibutuhkan komitmen dari komponen-komponen suatu organisasi yang dibangun dari komitmen masingmasing individu dalam organisasi. Komitmen tersebut dapat tertuang dalam perencanaan produksi untuk mencapai hasil yang diinginkan. Tujuan organisasi atau perusahaan disini adalah diperlukannya komitmen dari karyawan pada perencanaan produksi untuk menciptakan efektifitas pelaksanaan pengelolaan limbah. Setiap industri pasti mempunyai misi untuk melakukan bagaimana dan upaya meminimalisasi limbah dari proses produksi yang dilakukan. Hal tersebut perlu dilakukan oleh setiap industri agar kualitas lingkungan hidup tetap terjaga, dan juga untuk menjaga kesinambungan proses produksi. Keberhasilan dalam pelaksanaan 
pengelolaan limbah sangat dipengaruhi oleh komitmen karyawan dalam proses produksi yaitu bagaimana perencanaan produksi dilakukan. Hal tersebut terkait dengan manajemen yang dilakukan pada organisasi tersebut, bagaimana perencanaan produksi dilakukan dengan penggunaaan faktorfaktor produksi (tenaga kerja, biaya, material, peralatan atau mesin, cara kerja dan waktu). Dengan adanya komitmen karyawan yang merupakan keberpihakan karyawan terhadap perusahaan, dapat menjadikan karyawan terdorong untuk melakukan tugas dengan baik dan tanggungjawab dengan perencanaan produksi yang telah ditetapkan. Rasa tanggungjawab dalam melaksanakan tugas sesuai dengan perencanaan yang telah ditetapkan merupakan wujud adanya komitmen untuk mencapai visi dan misi dari perusahaan.

Proses timbulnya limbah Titan (TiO2) pada proses polimerisasi yang dihasilkan dapat dievaluasi dari 3 (tiga) sisi, yaitu metode produksi, mesin produksi dan material produksi. Limbah Titan ini termasuk jenis limbah bahan berbahaya dan beracun (B3). Dengan adanya limbah Titan tersebut yang dihasilkan pada persiapan dan TCD maka diperlukan upaya pengelolaan limbah tersebut dengan berbagai pendekatan seperti minimisasi limbah, pencegahan pencemaran, produksi bersih, responsible care, ecoefficiency, pembatasan pemakaian bahan-bahan berbahaya, desain berwawasan lingkungan, produktivitas ramah lingkungan, produk ramah lingkungan, mengubah lingkungan menjadi produk dan pertukaran limbah. Dalam pelaksanaan pengelolaan limbah tersebut diperlukan adanya komitmen dari karyawan untuk melaksanakan pekerjaaannya yang dalam hal ini dengan pendekatan perencanaan produksi.

Timbulnya limbah dapat terjadi mulai dari sisi metode, mesin dan material. Ditinjau dari Mesin; dapat dilihat dari fungsi scrapper dan drum. Pada scrapper yang mempunyai pengaruh adalah pisau scrapper dan waktu berputarnya scrapper. Dilihat dari fungsi scrapper perlu dievaluasi apakah dapat dilakukan modifikasi untuk mengurangi jumlah limbah yang dihasilkan (minimisasi jumlah limbah). Ditinjau dari Raw Material; terlihat padatan $30 \%$ dan cairan $70 \%$, artinya limbah yang dihasilkan dapat dikurangi jumlahnya, yaitu dengan cara memisahkan padatan dan cairan. Dilihat dari segi kondisi dan kualitas limbah dan partikel dengan ukuran besar maka tidak dapat dimasukan kembali dalam proses.

Ditinjau dari Metode; pertama dapat dilihat dari mode operasi scrapper dapat dilakukan dengan langkah auto atau manual. Pada mode auto, proses dapat dilihat pada proses TCD. Pada proses tersebut, setelah drum TCD berhenti berputar maka secara otomatis scrapp akan berjalan yang akan menyebabkan timbulnya padatan dan cairan sisa bercampur sehingga menghasilkan jumlah limbah yang besar. Dilihat dari penampungan sementara ternyata drum yang digunakan hanya drum biasa tanpa ada sentuhan modifikasi drum. Disamping itu juga, metode cara pelimbahan atau cara membuang limbah, ternyata belum ada dilakukan pengklasifikasian antara limbah padat dan cair.

Berdasarkan uraian di atas, maka perlu adanya komitmen karyawan pada perencanaan produksi sebagai upaya untuk mengurangi jumlah limbah yang 
dihasilkan dalam proses produksi tersebut. Komitmen karyawan tersebut dapat tertuang dalam langkah-langkah kerja yang dilakukan dalam proses polimerisasi mulai dari persiapan $\mathrm{TiO} 2$ dan TCD sehingga terwujud upaya efektifitas pelaksanaan pengelolaan limbah.

Komitmen karyawan dapat menumbuhkan semangat, motivasi bekerja dan adanya rasa keberpihakan kepada perusahaan, sehingga dapat meningkatkan kapasitas total karyawan untuk bekerja berdasarkan perencanaan produksi yang sudah disusun. Wujud dari komitmen karyawan pada perencanaan produksi yang merupakan salah satu unsur untuk mencapai tujuan dari perusahaan dapat terlihat yang salah satunya dalam pengelolaan limbah yang dilakukan. Dengan adanya komitmen karyawan pada perencanaan produksi berarti adanya rasa keinginan mencapai hasil yang maksimal sesuai dengan tujuan dan sasaran perusahaan. Untuk mencapai hasil yang sesuai dengan tujuan dan sasaran maka perlu adanya upaya yang dilakukan dengan dasar motivasi yang tinggi pada diri karyawan tersebut. Motivasi sangat penting artinya dalam mencapai suatu tujuan organisasi atau sasaran kerja.

Pada dasarnya pengertian efektifitas yang umum menunjukan pada taraf tercapainya hasil. Untuk pelaksanaan efektifitas perlu adanya manajemen dilakukan. Manajemen disini adalah mencakup kegiatan untuk mencapai tujuan yang dilakukan oleh individuindividu yang menyumbangkan upayanya yang terbaik melalui tindakantindakan yang telah ditetapkan sebelumnya. Manajemen dibutuhkan untuk mencapai tujuan, yaitu mencapai hasil yang maksimal dengan efektif. Untuk mencapai hasil dengan efektif tentu tidak terlepas dari efisien. Efektif selalu dikaitkan dengan pengertian efisien, meskipun sebenarnya ada perbedaan diantara keduanya. Efektifitas menekankan pada hasil yang dicapai, sedangkan efisiensi lebih melihat pada bagaimana cara mencapai hasil yang dicapai itu dengan membandingkan antara input dan outputnya. Dengan demikian, seorang manajer yang efektif dapat memilih pekerjaan yang harus dilakukan atau metode (cara) yang tepat untuk mencapai tujuan. Pada umumnya dalam organisasi, orang-orang yang paling menguasai dan menghayati program kerja dalam mencapai tujuan organisasi adalah orang-orang yang memegang jabatan eksekutif dalam organisasi.

Untuk mencapai efektifitas pelaksanaan pengelolaan limbah maka perlu ditingkatkan rasa keberpihakan karyawan pada perusahaan sehingga dalam pelaksanaan pekerjaannya karyawan mempunyai rencana yang jelas. Dengan perencanaan yang jelas, karyawan dapat melakukan kegiatannya sesuai dengan tujuan dan sasaran. Tercapainya tujuan dan sasaran berarti hasil yang dicapai efektif. Dengan demikian, dapat dikatakan adanya keterkaitan antara komitmen, perencanaan dengan efektifitas pelaksanaan. Jadi komitmen yang meliputi adanya keberpihakan, tanggung jawab dan motivasi dalam perencanaan produksi dapat mendorong karyawan untuk menghasilkan suatu pekerjaan yang sesuai dengan tujuan dan sasaran.

Berdasarkan hal tersebut di atas maka keberpihakan, tanggung jawab dan motivasi merupakan indikator adanya komitmen yang tertuang pada pelaksanaan perencanaan produksi yang meliputi menentukan metode kerja, 
perumusan kegiatan dan pengambilan keputusan yang saling mempengaruhi antar satu indikator dengan indikator yang lain, serta mempengaruhi tercapai atau tidaknya tujuan efektifitas pelaksanaan pengelolaan limbah.

\section{HASIL PENELITIAN}

Dari proses polimerisasi untuk menghasilkan Polyethylene Terepthalate (PET) menghasilkan limbah Titan Slurry yang tergolong limbah bahan berbahaya dan beracun (B3). Berdasarkan informasi yang diperoleh, selama ini departemen Polimer tidak melakukan pengolahan terhadap limbah Titan tersebut. Pengolahan terhadap limbah Titan tersebut dilakukan oleh jasa pengolah limbah yaitu PT. Pusat Pamunah Limbah (PPLI). Jadi yang dilakukan oleh departemen Polimer adalah hanya menampung limbah Titan yang dihasilkan dalam drum untuk di tampung dalam tempat penyimpanan sementara limbah B3 sebelum dikirim ke PPLI. Upaya yang harus dilakukan oleh Departemen Polimer adalah bagaimana mengurangi jumlah limbah titan yang dihasilkan.

Untuk mengurangi jumlah limbah Titan yang dihasilkan pada proses polimerisasi tersebut maka perlu dilakukan evaluasi terhadap timbulnya limbah Titan tersebut. Evaluasi tersebut dapat dilakukan dengan mengidentifikasi dari pendekatan metode kerja, mesin proses yang digunakan dan material atau bahan baku yang digunakan. Berdasarkan hasil temuan lapangan, jumlah limbah Titan yang dihasilkan per bulan sebanyak 24 (dua puluh empat) drum. Dengan demikian diperlukan berbagai pendekatan untuk mengurangi jumlah limbah Titan tersebut. Dengan adanya berbagai pendekatan tersebut diharapkan adanya efektifitas pelaksanaan pengelolaan limbah.
Dalam pelaksanaan proses produksi perencanaan yang dilakukan di Departemen Polimer PT. TIFICO salah satunya adalah proses persiapan dan pengontrolan material, yang tertuang dalam suatu prosedur yang telah ditetapkan. Tujuan dari prosedur ini adalah untuk menjamin agar persiapan bahan baku dan proses produksi dilakukan dengan benar sehingga kegiatan proses produksi dapat terlaksana sesuai dengan yang telah direncanakan. Adapun ruang lingkup dari prosedur tersebut adalah mendefinisikan aktivitas dan tanggung jawab bagian produksi dalam menyiapkan bahan baku, barang-barang pendukung dan sarana yang dibutuhkan untuk proses produksi. Jadi dalam persiapan proses polimerisasi telah ditetapkan prosedur persiapan dan pengontrolan material pada tahap perencanaan produksi. Persiapan dan pengontrolan material sangat mendukung pelaksanaan proses produksi.

Melalui analisa deskriptif yang diukur dari setiap indikator dari ketiga variabel dalam penelitian ini, yakni : (1) variabel komitmen karyawan, (2) variabel perencanaan produksi dan (3) variabel efektifitas pengelolaan limbah diperoleh hasil sebagai berikut :

1. Komitmen karyawan yang diukur meliputi tiga indikator yaitu indikator keberpihakan, tanggung Jawab, dan motivasi. Berdasarkan pada perhitungan dapat diketahui bahwa diantara ketiga indikator yang berasal dari variabel komitmen karyawan, indikator keberpihakan memperoleh skor tertinggi yaitu 1041 atau $86,75 \%$ dari yang diharapkan. Indikator motivasi berada pada posisi kedua yaitu memperoleh skor 1649 atau 85,89\% sedangkan yang paling terakhir dari 
ketiga indikator yang diukur berdasarkan variabel komitmen karyawan adalah indikator tanggung jawab yaitu sebesar 874 atau 80,93\%. Hal ini bila dikaitkan dengan proses polimerisasi dalam menghasilkan Polyethylene Terepthalate (PET) yang menghasilkan limbah Titan Slurry dapat dilihat dengan adanya keberpihakan dari karyawan akan menimbulkan rasa ingin adanya perbaikan dalam proses polimerisasi tersebut. Dengan adanya perbaikan dalam proses polimerisasi tersebut diharapkan dapat mengurangi jumlah limbah Titan yang dihasilkan. Dengan demikian untuk menunjang efektifitas pelaksanaan pengelolaan limbah perlu adanya komitmen yang kuat dari karyawan.

\section{Perencanaan produksi diukur} untuk tiga indikator yaitu penentuan metoda kerja, perumusan kegiatan, dan pengambilan keputusan. Berdasarkan perhitungan dapat diketahui bahwa diantara ketiga indikator yang berasal dari variabel perencanaan produksi, indikator menentukan metode kerja memperoleh skor tertinggi yaitu 1347 atau 86,35\% dari yang diharapkan. Indikator pengambilan keputusan berada pada posisi kedua yaitu memperoleh skor 719 atau 85,60\% sedangkan yang paling terakhir dari ketiga indikator yang diukur berdasarkan variabel perencanaan produksi adalah indikator perumusan kegiatan yaitu sebesar 1113 atau 84,32\%. Dengan demikian diketahui bahwa proses timbulnya limbah Titan dalam proses polimerisasi dipengaruhi oleh adanya faktor metode kerja yang digunakan, mesin proses yang digunakan dan material yang dibutuhkan. Melihat faktor tersebut maka dengan adanya evaluasi terhadap metode kerja dalam proses polimerisasi dapat mengurangi jumlah limbah Titan yang dihasilkan. Dengan adanya perubahan metode kerja dalam proses polimerisasi maka dapat menyebabkan efektifitas pelaksanaan pengelolaan limbah yaitu mengurangi jumlah limbah Titan yang dihasilkan.

\section{Efektifitas Pelaksanaan Pengelo-} laan Limbah diukur untuk tiga indikator yaitu program kerja, perumusan kegiatan, dan ketepatan tindakan. Berdasarkan pada perhitungan dapat diketahui bahwa diantara ketiga indikator yang berasal dari variabel efektifitas pengelolaan limbah, indikator kesesuaian kemampuan memperoleh skor tertinggi yaitu 208 atau 77,04\% dari yang diharapkan. Indikator program kerja berada pada posisi kedua yaitu memperoleh skor 208 atau 76,67\% sedangkan yang paling terakhir dari ketiga indikator yang diukur berdasarkan variabel efektifitas pengelolaan limbah adalah indikator ketepatan tindakan yaitu sebesar 76 atau 63,33\%. Hal ini berarti dalam proses polimerisasi tersebut harus didukung oleh program kerja yang telah ditetapkan sebelumnya. Salah satu program kerja yang harus ditentukan adalah kebutuhan material yang akan digunakan mulai dari jumlah bahan baku yang akan digunakan, kandungan dari bahan baku serta kondisi dan kualitas bahan baku yang akan digunakan. 


\section{KESIMPULAN DAN SARAN}

\section{Kesimpulan:}

Berdasarkan pada temuan penelitian dan pembahasan penelitian, maka dapat disimpulkan sebagai berikut:

1. Efektifitas Pelaksanaan Pengelolaan Limbah dapat dilakukan oleh Departemen Polimer PT. TIFICO dengan pendekatan adanya komitmen karyawan dan perencanaan produksi dalam proses polimerisasi.

2. Komitmen karyawan melalui adanya rasa keberpihakan karyawan terhadap perusahaan akan menimbulkan dorongan untuk melakukan pengembangan proses produksi yaitu menciptakan pemikiran inovasi proses produksi. Dengan demikian jumlah limbah Titan yang dihasilkan dapat diminimalisasi.

3. Pendekatan perencanaan produksi melalui penentuan metode kerja dalam proses polimerisasi dapat mengurangi jumlah limbah Titan yang dihasilkan. Melakukan modifikasi rancangan kerja yang tertuang dalam metode kerja berdasarkan hasil proses produksi sebelumnya.

\section{Saran}

Berdasarkan hasil penelitian, kesimpulan dan implikasi, berikut beberapa saran yang dapat disampaikan untuk dapat dilakukan:

1. Untuk meningkatkan komitmen karyawan maka perlu adanya pemberian penghargaan (reward) bagi karyawan yang berprestasi.

2. Diperlukan adanya inovasi proses produksi yang antara lain melakukan modifikasi proses, yang dapat mendukung pengurangan jumlah limbah yang dihasilkan.

3. Perlu adanya komunikasi yang baik antar sesama karyawan dan juga pemilik perusahaan sehingga tercipta suasana kerja yang kondusif dan nyaman.

4. Perusahaan agar melakukan peningkatan kualitas dan keterampilan karyawan dengan menyediakan sarana dan prasarana serta memberi kesempatan pada karyawan untuk mengikuti pelatihan-pelatihan terkait dengan pengelolaan limbah bahan berbahaya dan beracun (B3).

\section{DAFTAR PUSTAKA}

1. Amin, Mufham Al. Manajemen Pengawasan, Jakarta: Kalam Indonesia 2006.

2. Arikunto, Suharsimi. Manajemen Penelitian, Jakarta, PT. Rineka Cipta, 2005.

3. Atmosoeprapto, Kisdarto. Menuju SDM Berdaya dengan Kepemimpinan Efektif dan Manajemen Efisien, Jakarta: PT Elex Media Komputindo Kelompok Gramedia, 2002.

4. A. Usmara (ed), Paradigma Baru Manajemen Sumber Daya Manusia, Yogyakarta: Amara Books, 2002.

5. Dessler, Gary. Human Resource Management, United States of America; Pearson Education International, 2003.

6. George, R. Terry. Dan J. Smith D.F.M Prinsip-prinsip Manajemen Jakarta Bumi Aksara, 2003.

7. Gibson, James L. And John M. Ivandevich and James H. Donnelly, 
Jr 1995, Organisasi, Perilaku Struktur Proses, Edisi 8, Alih Bahasa Nunuk Adiarni, Binapura Aksara, Jakarta.

8. Handoko, T. Hani. Dasar-dasar Manajemen Produksi dan Operasi Yogyakarta, BPFE, 1987.

9. Henry, Simamora. Manajemen Sumber Daya Manusia. Yogyakarta: Bagian Penerbitan Sekolah Tinggi Ilmu Ekonomi YKPN, 1995.

10. Lembaga Penelitian Universitas Indonesia dan Kementerian Negara Lingkungan Hidup, Studi Analisis Kebijakan Perencanaan Pengelolaan Lingkungan Hidup, 2002.

11. Manulang, M. Dasar-dasar Management Jakarta: Ghalia Indonesia, 1987.

12. Mardiasmo, 2002, Akuntansi Sektor Publik, Penerbit Andi Yogyakarta.

13. Peraturan Pemerintah RI. Nomor 18 tahun 1999 tentang Pengelolaan Limbah Bahan Berbahaya dan Beracun.

14. Rafinus, Robby Hamzar. Sistem Pengelolaan Pembangunan Jakarta: Lembaga Admnistrasi Negara RI, 2003.

15. Rao, TV. Penilaian Prestasi Kerja, terjemahan Ny. L. Mulyana, Jakarta: PT. Gramedia, 1986.
16. Robbins, Stephen P. Perilaku Organisasi, terjemahan Tim Indeks, Jakarta: PT INDEKS Kelompok Gramedia, 2003.

17. Robbins, Stephen P. /Mary Coulter, Manajemen, Edisi kedelapan.

18. Sudrajat, Wawan Kustiawan, Marlon I. Aipassa, Manajemen Lingkungan Kerja, Direktorat Jenderal Pendidikan Tinggi, Departemen Pendidikan dan kebudayaan, 1998.

19. Triguno, Budaya Kerja, Penerbit PT. Golden Trayon Press-Jakarta.

http://www.en/articlesgratuits.com/o rganizational-commitment-id1530.php.

http://indosdm.com/komitmen karyawan dan budaya kerja.

http://ronawajah.wordpress.com/200 8/06/15 menciptakan komitmen karyawan.

http://www.ppbn.or.id/site/index penerapan Ekoefisiensi - Produksi Bersih pada Kluster UKM di Indonesia melalui 9 Langkah.

http://www.menlh.go.id/home/index Kebijaksanaan Produksi Bersih di Indonesia 